\title{
Kidnap: Exploring Guilt and Its Impacts towards Individuality
}

\author{
Yosodiharyo, I. S. \\ English for Creative Industry, Faculty of Letters, Petra Christian University, Siwalankerto 121-131, Surabaya \\ 60236, East Java, INDONESIA \\ Email: m11413005@john.petra.ac.id
}

\begin{abstract}
Crime films usually focus on solving criminal cases or exploring the victim's story. This creative work that I make, however, follows the story of a criminal who is given a mission to kidnap the successor of a wealthy CEO but mistakenly kidnaps another person instead. He is captured in a dilemma whether to let her go, and his situation gets worse when he is given a new order to kill her. The story revolves around the criminal as the true motive is revealed. With the boundary of good and bad being questioned, this work hopefully reminds people to be less judgmental towards others. The theme in this work is how guilt changes a person's personality and way of thinking. The psychology of guilt is used for the main theory in this work. The story is presented through the genre psychological suspense, which normally focuses on a crime and its complexity.

Keywords: Crime, Kidnapping, Guilt, Psychological Suspense, Gray Area
\end{abstract}

\section{INTRODUCTION}

As my final project, I decide to make a screenplay which will be made into a fifteen-minute short film. The genre that I choose is a subgenre of crime drama, which is psychological suspense. This genre sets its focus on the complexity of a crime and the motivation behind a criminal behavior (Vaughn, 2008). I found this genre suitable because I would like to set the focus of my story on the feelings and thoughts of the main character, who is a criminal, which influence his actions as the story goes by.

Through this creative work, I would like to raise a question regarding the boundary between good and bad, which is more complicated than it seems. There are a lot of examples of good and bad behavior, and among the vast varieties of those, I choose to use crime as it is something inevitable in our daily lives. Now that people are surrounded by crimes and wrongdoers, they began to draw a line between themselves and the criminals who are labeled as the 'bad people'. However, the fact is there are reasons behind these crimes and they explain how a person turns into one of those 'bad people' mentioned earlier. In fact, this line that people draw to separate themselves from the wrongdoers is not a distinct line at all; it is more like a gray area (Gargan, 2016), which caught my interest.

As the boundary between good and bad is extremely blurry, it is easy for people who are said to belong to one side to jump into another. Sometimes people could also be mistakenly judged as either one of the two categories. Society tends to judge people based on how they look or what they do without bothering to care about their background and what they have been through. This makes me think: what if those criminals are not exactly who people think they are?

In delivering this idea about the uncertainty of the gray area, I choose to set my story in a kidnapping scene. The motive behind kidnapping in general can be divided into two, which are expressive and instrumental. According to David A. Alexander and Susan Klein, "an expressive motive means someone commits the crime to voice grievance or to express a frustrated emotion, and an instrumental motive means someone commits the crime to obtain a particular outcome such as ransom" (Alexander and Klein, 2009). This material outcome could be used for religious or political activities (ibid.). At this point, it can be seen that the gray area that stands between good and bad cannot has its own complexity. Through this project, I want to explore the background of the kidnapper which drives him to commit such crime and whether he is truly one of the "bad people" that he seems to be.

In short, this screenplay that I make follows a story of a young man who commits the crime of kidnapping. He might appear to be a violent criminal, but he actually holds a story that is much deeper than that. I want to use him to highlight the blurriness of the gray area. As the story goes on, the audiences 
will see that he is not as bad as he seems and he has reasons why he becomes a criminal. These reasons will make the audiences rethink about whether he can really be labeled as a "bad person", and also to show how sometimes people wear masks that hide who they really are.

A criminal's thought that becomes the underlying reason for committing a crime is not always negative; it could be the other way around. At this point, determining someone as good or bad becomes harder than it seems. Therefore in this project I would like to explore what drives the Man to kidnap and eventually choose to kill the Woman, and what happens to the Man when he has to decide to kidnap and kill the Woman.

The purpose of this work is to make the audience realize that the barrier between good and bad barely exists and that human beings cannot be judged simply based on their appearance and what they do. To be more specific, through this project, I would like to show how the Man's guilt from his past greatly affects his personality as he grows and his choice of action, and to also show the dilemma that the Man has to go through as he kidnaps someone and chooses whether or not to kill her.

In making this work, I decide to choose guilt as the theme. Therefore, I would like to refer to the theory of the psychology of guilt in order to have a deeper understanding of how guilt is formed within one's self and how it can motivate a person to do a certain action. Guilt belongs in the general category of negative feeling state. This emotion emerges when someone thinks that he or she has caused harm or misfortune towards another person, whether or not it actually happens. Guilt is often the tendency to misinterpret what happens.

Guilt can be classified into five (Whitborne, 2012). However, out of those five I will only be using four of them. The first one is guilt for something a person did, in which a person feels guilty because he or she has done something that harms others, or because of violating a personal moral principle. The second one is guilt for something that a person did not do but wanted to do. It emerges when someone wishes to do something against a moral value, even though at the end the person manages to restrain the action. The third one is guilt for something a person thinks he or she did. Sometimes a person might misremember things and assumes that he or she has committed something harmful even though in fact it does not happen. The fourth one is guilt because a person thinks he or she did not do enough to help another. For instance, a person wants to help a sick friend but something stands in his way which prevents him from doing so. As seen here, guilt itself is a unique and complex emotion.

Guilt has a strong connection to the thought of doing harm towards others. What makes a person thinks so comes from the understanding of the concept of approval (Erupting Mind, 2016). Children, for example, always seek for their parents' approval. When children do something morally acceptable, parents praise them and children begin to understand that getting their parents' approval is a way to receive love and acceptance that they desire. As they grow older, they apply the same concept in order to be accepted by others in society. As humans also learn about moral values since childhood, they have their own values that they strongly hold onto. Therefore, when they do something that displeases others or violates their own moral values, they feel like they have lost others' approval. At this point, guilt develops and encourages the need to get back the approval.

In my work, I decide to create a background story for the main character in which he is put in certain circumstances that pressures him to fulfill an obligation and do whatever it takes to achieve it, even though it might be against his principal values. In this case, the Man's tough past along with his experience with his family, especially his mother, has triggered guilt to emerge within himself. His guilt motivates him to push his limit. Guilt becomes the core of all his actions.

\section{OUTLINE OF THE CREATIVE WORK}

\subsection{Theme}

The theme in my screenplay is how guilt changes a person's personality and way of thinking. His guilt that grew from the time when he failed to save her mother's life eventually enhanced his sense of survival. Guilt becomes the core of his motivation for committing the crime. It also affects his perception of right and wrong. The main character is totally aware of the fact that he is doing something 
morally unacceptable but he interprets it as a way to support his family, which lets him justify his action. Through this kidnapping event the audience can see how the interpretation of 'right' and 'wrong' can vary depending on the situation.

\subsection{Characters}

\subsubsection{Major Character:}

The Man

Age : 25 years old

This man has been living a hard life since he was little. Born in a poor family, he had to start doing some work to earn extra money since a really young age, especially after his father left the family and there was nobody else to rely on for financial support. He is quite shorttempered and is rather rude, but he loves his mother and younger sister tremendously. As they grew older, the man found it harder to support them both. The hardest moment in his life was when his mother fell sick and needed to be treated in the hospital. Her condition only got worse until she reached a point where her life was completely dependent on a life supporting machine. Keeping his mother in the hospital, however, cost a huge amount of money and no matter how hard he tried, he just could not afford it anymore. The fact that he still had his sister to take care of only made situation worse. This forced the man to make a decision to let his mother go forever, which left him with immense guilt. Not too long after the death of his mother, he got an offer from a guy he never knew before to join a dark organization. He knew that if he joins the organization, he would have to do things far worse than what he had done before. However, his guilt from the past assures him that what he has done before for his family was never enough, and that he has to do something more. Therefore, he decided to accept the offer, especially with a huge amount of money promised in return which might help his family a lot. He does not know who the boss of the organization is, because the one who always deals with him is the Guy. The Man does not know that when he is given the "first mission", actually he has not been officially hired yet and that the mission is only a test.

\subsubsection{Supporting Character: The Woman}

Age : 24 years old

The woman is a cold-hearted, independent, self-centered head of a dark organization. She was raised only by her father, who was the former head of the organization. As a child, she was shaped to be her father's successor. Since an early age, she was exposed to the world of criminals and injustice. She was raised as someone who always has to be on the winning side and to always have her wishes fulfilled no matter what it takes. She trusts nobody but herself. This is why instead of just sitting back while her employee is looking for another man to join her team, she decides to jump in and pretends to be an innocent young woman while the man is torn between the choice whether or not to let her live -she knows she will be alive by the end of it as it is a game that she designs herself so she never worries about it. She has some traits of psychopathy, in which she appears cool, calm, or even charming at some point. Unlike a sociopath who tends to have an emotional outburst and is rather disorganized when committing something, a psychopath like her is able to plan everything meticulously (Bonn, 2014). She takes pleasure in seeing other struggles with their problems, and she also has the ability to mimic others' emotion despite her inability to feel them.

\section{The Guy}

Age : 28 years old

He has been working for the organization for quite some time and is a loyal employee to both the woman and her father. He is the one who does the "scouting" to find a new member for the organization and he sets his eyes on the Man. He gets to know the Man along with his 
background and then lets the Woman know about this new candidate for the organization. He is the one who gives the mission to the Man and interacts with him all the time.

\subsection{Conflict}

The main conflict of this story is an inner conflict of the Man. First, he is contemplating about the option whether or not he should release the Woman. He feels bad because he has hurt an innocent person, but for his sake, he cannot simply let her go because it will make his failed mission even worse. It reaches its climax when he is told to kill the woman. He believes that he should never kill anyone who does nothing against him, but, killing her, who is only a, might actually save his sister and himself. Moreover, he does not want to repeat the tragedy that happened to his mother.

\subsection{Setting}

The story takes place in an abandoned warehouse. The Man is told to bring the Woman there once he manages to kidnap her. The warehouse is mostly empty, only filled with some crates and chairs. It is dusty with some trashes and empty bottles scattered around the floor.

\subsection{Pitch}

a. A Man kidnaps a young Woman who is said to be the heiress of a rich CEO and forces her to tell him the code to her father's company vault. The Man later found out that he kidnaps the wrong person.

b. The Woman keeps on begging the Man to let her go, but a Guy who turns out to be the Man's senior in a dark organization that he is working for comes and tells him to kill her instead if he still wants to get some money.

c. The Man finally makes a difficult choice to kill her, but then it is revealed that the whole thing is just a test and the Woman is actually the boss of the organization who is there to test him.

\subsection{Synopsis}

A young man is seen kidnapping a young woman who is said to be a daughter of a rich, nowdeceased CEO. He takes her to an abandoned warehouse and keeps on pushing her to give him a code to her father's company vault. However, the Woman says she does not understand anything and that the Man might have mistaken her for the CEO's daughter because they look alike. The Man does not believe her and keeps on torturing her, still demanding the code.

All of a sudden, the Woman has a panic attack. She asks the Man to take her medicine inside her bag. The Man is reluctant at first but he cannot let anything happen to her as he does not have the code yet, so he decides to help her. The Woman's condition eventually gets better, and the Man finds the Woman's wallet lying on the floor. He sees her name card, which shows a completely different name from the name of the person that he is told to kidnap. He realizes that he kidnaps the wrong person and starts to panic. He goes outside for a smoke to calm himself a little bit.

When he goes back inside the room, the Woman continues to beg him to let her go. The Man does not know what to do, and things only get worse when a guy, who turns out to be the Man's senior, shows up and asks for the code. The Man explains that he gets the wrong person because the Woman's look is extremely similar to the one he is supposed to kidnap. The Guy says that the Man has failed the mission, but since he does it anyway, the Guy is willing to give half of the amount of money that he has promised to the Man if the Man kills her. The Man is against the idea, but the Guy reminds him of his mother who fell sick and died because the Man did not have enough money to save her life. Overwhelmed by guilt and burdened by the thought that he still has a younger sister to be taken care of, the Man decides to shoot the Woman with a gun that is already prepared for him.

To his surprise, the gun is filled with blanks and it is revealed that the Guy is actually working for the Woman, which means that she is the boss of the organization. The whole mission thing turns out to be a test that the Woman makes to decide whether or not she can accept the Man as one of her men. 


\subsection{Step Outline}

1. A man is seen taking an unconscious woman inside a warehouse. He then takes a gun that is hidden in a nearby crate. He keeps it inside his pocket and closes the warehouse door.

2. Waiting for the Woman to wake up, the Man sits at the corner of the room while looking at a family photo.

3. The Woman finally wakes up. She finds herself all tied up on a chair and begins panicking right away.

4. The Man comes closer to the Woman and sits in front of her, telling her that there is nobody around to help her asks her to give him a code to her father's company vault.

5. The Woman looks confused and says she does not know anything.

6. The Man slaps her, but she still says that she does not know anything about the code. The Man keeps on slapping her as she continues to cry.

7. The Man threatens her with a gun. However, the Woman still insists that she is not the one that the Man is looking for.

8. The Man takes out a photo from his pocket. The person in the photo looks exactly like the Woman. The Man refers to the person in the photo as Kim Hye In, a daughter of a rich CEO who recently died in a car accident. The Man is sure that the Woman is Kim Hye In and he assumes she knows the code to the CEO's company vault.

9. The Woman tries to explain that she is not Kim Hye In, but the Man does not believe her.

10. The Man fires the gun to the wall behind him then presses the scorching barrel against her thigh, and it seems that this has triggered the Woman to have a panic attack.

11. The Man immediately panics when he sees the Woman's body starts shaking. She tells him that she has her medicine in her bag.

12. The Man cannot let anything happen to the Woman without having the code. Beside, deep down inside he does not want to see anyone dies. He decides to help her. He throws everything out of the Woman's bag to find the medicine and makes the Woman drinks it.

13. The Woman's condition eventually gets better as she starts to calm down. She seems to almost fall unconscious for a while.

14. The Man sees the Woman's wallet lying on the ground. He opens it and finds her name card. It says that her name is Lee Bo Young and that she works as a graphic designer. Realizing that he has kidnapped the wrong person, the Man gets even more panicked. He goes outside to have a cigarette and to calm himself down a little bit.

15. After a while, the Man goes back inside the warehouse. The Woman is already conscious and she immediately asks the Man to let her go. She even offers him some money, but the Man ignores the offer.

16. The Woman starts asking him about what is going on. She asks him about the code that he is trying to get; what is so important about it that he has to risks an innocent person's life and what will happen if he does not get the code. The Man refuses to answer. The Woman starts to bother the Man by asking question about his family and whether they will be okay if he is doing something like this. The Man immediately tells her to shut up.

17. The Woman brings up the fact that the Man still saves her life earlier. She tells him that she thinks he is actually not as bad as he is trying to be. She continues to beg him to let her go. The Man only mumbles that he cannot let anyone down anymore, to which the Woman asks what he means.

18. Before the Man can answer the question, the warehouse door is suddenly slammed open. A guy comes in, asking the Man to give him the code.

19. The Man tells the Guy that he kidnapped the wrong person. He shows the photo to the Guy and insists that the Woman looks similar to the person in the picture.

20. The Guy tells the Man that the Woman is probably just fooling with him and that she would not give her true identity that easily. However, the Guy says that if the Man is sure that he 
kidnaps the wrong person, then the Woman should be killed instead. The mission will be counted as a failure, but the Guy is still willing to give the Man some of the money that has been promised for the mission.

21. The Man is against the idea of killing the Woman. He says that he was told the mission will be nothing more than asking a code. It says nothing about killing anyone and he has never killed anyone in his entire life. To the Man's surprise, the Guy chuckles and says that the Man is lying.

22. The Guy starts talking about the Man's mother. He reminds the Man that his mother was once sick and her life depended on a life supporting machine. However, since the Man did not have any money to pay for the treatment, the Man decided to take the machine off and let his mother die.

23. The guilt that the Man has always had inside him starts to rise up, and he is reminded of his younger sister who still needs him. He is left in dilemma. On the one hand, he is holding on to the moral value that he should never kill anyone, especially someone innocent who does not have anything to do with him. On the other hand, he needs a lot of money so badly to support his sister. He does not want to repeat the same mistake that he made with his mother twice. The remorse inside him finally drives him to go with the choice of shooting the Woman.

24. The Man shoots the Woman, but she does not die. He fires the gun a few more times, and realizes that the gun is filled with blanks. He is confused.

25. The Woman starts to laugh creepily. She unties the rope around her ankles and wrists by herself and stands. The Man is stunned.

26. The Guy comes to her. He talks to her in a manner that is full of respect, and tells her that he would prefer the woman to stay out of this. The Woman, however, says that she feels bored if she has to wait around while the Guy is testing her soon-to-be employee, so she would rather be here and see the candidate -the Man, with her own eyes.

27. The Man is extremely confused with the situation. He keeps on asking what is going on but nobody answers him.

28. The Woman tells the Guy to give the money to the Man.

29. The Guy follows the Woman's order. He gives the Man the money and takes him out of the warehouse.

30. The Man desperately asks what is going on and who they are. He suddenly hears a gun being fired from his back. The Woman stands behind him. She chuckles and tells the Man that he has passed the test.

\section{CONCLUSION}

Through this project, I learned how difficult it is to create a screenplay that could offer an interesting appeal to the audience. The storyline of my work is already common to start with. I tried to think of a way that could raise the audience's curiosity when they watch my short film. I finally came up with the decision to put a twist at the end of my story, which would turn the whole story upside down.

I found that references and opinions are always a helpful in making a screenplay. Doing a lot of reading and watching might enable a writer to broaden his or her options when writing a script. Unfortunately, this was quite hard to do under my circumstances, as I only had two months before my shooting started. I only found a small number of references that I used for my work. Even so, those references were still very helpful. I also tried to get as many opinions as I could. However, later on I learned that too many opinions could be confusing. Even though being open to people's opinion is important, I should have tried to get opinions from only a few people whom I really trust so that I would not get too confused. Also, the final choice still needed to rely on my own thoughts and what I really wanted to convey in my short film.

Another important thing that I get through this work is time management. It was really difficult to organize my time especially because I was the screenwriter and the director. There were also some 
classes that I took, so I had to balance between working on the pre-production process and doing my best in classes as well. Luckily, after a while I managed to create a daily schedule and I tried not to postpone anything to keep everything organized.

The process of making this screenplay and working on its production at the same time was a whole new experience for me. Throughout the production, I learned that sometimes I had to be flexible with my work. The production situation kept on changing and I had to keep myself updated with the information from the production crews. I had to think of a way to work with my script so that we would be able to shoot with the allocated budget. I also had to revise my script and cut some scenes in order to shoot with fewer actors and save some budget. I also needed to make another revision after I got the location for my shooting. The scriptwriting process was extremely difficult with all the revisions that I had to do within the limited time, but it was truly a great opportunity.

I truly believe that I still have a lot of improvements to do as a screenwriter. I would like to explore more genres and find more sources to read or watch in order to help me find a style that really suites me. Making more short films is also another goal that I want to accomplish, as I believe practice is the real guru. This short film that I made still looks like it is a part of a feature-length film. It seems like my work still has more untold stories to tell aside from those that I deliver within fifteen minutes. I want to practice more, so that later if I have another opportunity in the future to make a short film I can deliver the story as a whole within the limited duration.

I am aware of the fact that my work is still far from perfection. Therefore, I would like to show the final result of my work to other people which allows me to get some honest opinions and suggestion that I can keep in mind when I work on my upcoming project. I also hope that I can submit my work in film festivals.

Working on this project has allowed me to explore more about psychological processes that shapes a person's personality. Choosing a criminal as the center of my story has opened my eyes to the many causes of a crime and the characteristic of the perpetrator. The main psychological element in my work, guilt, is only one of the many underlying factors behind a criminal behavior. There are still a lot more factors that can be focused on. There is one factor that really catches my interest, and that is psychopathy. I read some articles about the psychology of a psychopath to help me build the character of the Woman in this story. However, I did not really go deeper into her character because the main focus of my story should still be the Man, not her. I find that understanding how a psychopath's mind works is quite a challenge, and it will be great to be able to dig deeper into it. It would be good to see other works out there which explore more about this problem and how to deal with it.

Throughout the process of making this project, I also found that a crime story is often combined with genres such as thriller or drama, or action. The atmosphere is usually dark and distressing, and it is suitable for the story that I want to deliver because it suits my main character's thoughts and emotion. Nonetheless, I think it would be good to do something out of the box and explore this story through other genres as well, such as comedy, horror, or maybe even fantasy. The Grand Budapest Hotel and Kingsman: The Secret Service are some examples of a work I have seen which combines the criminal elements with a touch of comedy. However, I rarely see other works with this kind of combination. Therefore, delivering a crime story through genres that are not commonly linked with crimes could also be an interesting method in storytelling, as we could work with more elements that people would not expect to find in an ordinary crime story.

\section{REFERENCES}

Alexander, D. A., \& Klein, S. (2009). Kidnapping and hostage-taking: a review of effects, coping and resilience. $\quad$ Retrieved February 25, 2017, from https://www.ncbi.nlm.nih.gov/pmc/articles/PMC2627800/

Bonn, S. A., Ph.D. (2014). How to tell a sociopath from a psychopath. Retrieved March 20, 2017, from https://www.psychologytoday.com/blog/wicked-deeds/201401/how-tell-sociopath-psychopath 
Buffam, N. (n.d.). Genre: Drama. Retrieved February 25, 2017, from http://thescriptlab.com/screenplay/genre/drama

Gargan, I. (2016). The line between good and bad people can be thinner than you think. Retrieved February 25, 2017, from http://www.thejournal.ie/readme/ian-garage-the-line-psychology3029332-Oct2016/

Psychological Suspense. (n.d.). Retrieved February 25, 2017, from http://www.toledolibrary.org/blog/psychological-suspense

Smithwick, F. (2015). On writing psychological suspense. Retrieved February 25, 2017, from http://booksbywomen.org/on-writing-psychological-suspense/

Understanding the psychology of guilt. (n.d.). Retrieved February 26, 2017, from http://www.eruptingmind.com/the-psychology-of-guilt-overcoming-types-of-guilt/

Vaughn, M. J. (2011). Sub-genre descriptions. Retrieved April 17, 2017, from http://www.writersdigest.com/qp7-migration-all-articles/qp7-migrationfiction/genredefinitions

Walker, J. (2017). \#Publishing: what is psychological suspense? Retrieved February 25, 2017, from http://jeriwb.com/what-is-psychological-suspense-6856/

Whitbourne, S. K. (2012). The definitive guide to guilt. Retrieved April 17, 2017, from https://www.psychologytoday.com/blog/fulfillment-any-age/201208/the-definitive-guide-guilt 